\title{
RELATIONSHIP MARKETING AS A TOOL FOR GAINING COMPETITIVE EDGE AND PROFITABILITY IN THE BANKING INDUSTRY: AN EMPIRICAL ANALYSIS
}

\author{
Ifediba Emmanvitalis, Emeka. Ph.D \\ Marketing Department Madonna University, Okija Campus. \\ Anumege Sebastian, Chibunna. Ph.D \\ Marketing Department Madonna University, Okija Campus. \\ DOI: 10.47760/cognizance.2021.v01i06.001
}

\begin{abstract}
This study was carried out to examine how relationship marketing servers as a tool for profitability in banking industry in Nigeria. This study investigated ten (10) commercial licensed banks which were chosen at random from different locations in Lagos State: Zenith Bank, First Bank, United Bank for Africa plc, Access Diamond, Sterling Bank, Heritage Bank, Polaris Bank, Wema Bank, Guarantee Trust Bank and First city monumental plc. The study employed primary data collected in ensuring that valuable data were obtained for the data analysis. A total number of one hundred and twenty (120) copies of questionnaire were administered to staff of the selected banks for which (110) were used for analysis. After cleaning and sorting the copies of the accepted questionnaire they were fed into the statistical package for social science (SPSS). The questionnaire was structured in line with the research objectives, questions and hypothesis of the study. The Pearson product moment correlation coefficient was used to confirm formulated hypotheses. The study found that relationship marketing in Nigeria banks improves the bank's profitability and that the presence of valuable and high-quality products and services enhances the bank profitability. The study concluded that, banks' most important assets are the customers and as such, they need to be managed in a manner that will ensure that their expectations are met. The study also recommended that the relation managers and other managers, the staffs in the related departments and other stakeholder involved in matters of the bank's operations continue with the spirit of understanding the requirements of Relationship Marketing, as well as other issues that governs it.
\end{abstract}

Keywords: Relationship Marketing, Marketing concept, Banking, SPSS.

\section{INTRODUCTION}

The banking sector is becoming increasingly competitive around the world. This is particularly true in the area of small-medium business banking. Further, the core and actual product being offered to business customers could be considered reasonably homogenous. Consequently, there is an increased need for banks to differentiate themselves from competitors at the augmented product level. In the increasingly competitive global financial world, relationship marketing has been advocated as an excellent way for banks to establish a unique long-term relationship with their customers.

The definition of relationship marketing (RM) can be inferred from its name to basically mean the way by which personal relationship is been developed with customers by an organization. It 


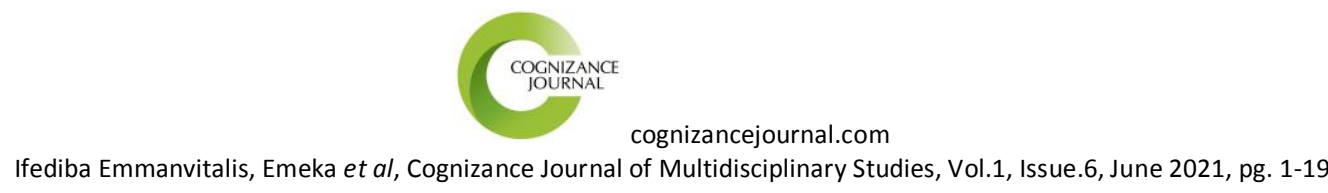

ISSN: 0976-7797

is very easy to start a business but difficult to build a strong customer relationship. Increasing need of relationship marketing has gingered attention to the area of consumer trust and satisfaction in order to establish, develop, and maintain an efficacious personal relation.

Any organization that wants to build a business successfully from the onset must take relationship marketing seriously. Building a relationship with your customer therefore, requires you to know your customers very well. It is a designed strategy that is used to grow customer loyalty, interaction and long-term engagement. Top management officials in banks recognize the fact that establishing a strong relationship with customers will ensure long-term profitability and sustainable core profits.

However, both the service providers in bank and the customers must enjoy the advantage of relationship in the long term (Dimitriadis, 2011). When relationships improve between the banks and its customers, efficiency and quality of service being rendered in the bank will also increase (Brige, 2006). Nowadays, through the extensive practice of electronic communication technologies, customer relationship management has experienced substantial changes and it characterizes a system which comprises all facets of communication and interaction with customers. In another way round, it determines how to interact with customers, provide solution to their needs, encourage them to patronize banking products and services, create a sense of loyalty and sustain financial connections with customers (Rezghi, Valmohammadi, \& Yousefpoor, 2014).

Generally, banks that see the importance of establishing strong relationships with customers stands a better chance in retaining these customers in the long term by providing them with extra worth tailored to meet their needs. In order to meet customers' need, better understanding of customer demographics and behavioural patterns is required (Estrella-Ramón, 2017). Customer satisfaction is attained through the experience that a customer has with a product/service they consumed in contrast with what they expected. The customer who is satisfied with a product or service will probably purchase again and also relate his or her experience with the consumption of the product or service to others. A satisfy customer also have a tendency to maintain his or her loyalty to that particular product or service because they will not see any reason why they should switch to another one since they have already derived a form of satisfaction from one. 


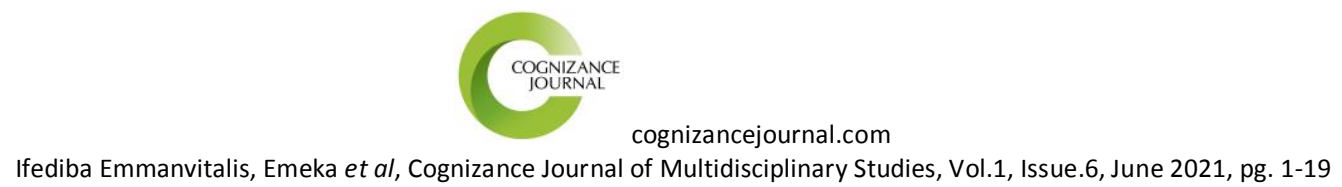

ISSN: 0976-7797

Notwithstanding, the fact remains that building a good relationship that will be long lasting is not an easy task in the banking industry due to the turbulent competition in the industry. In the light of the foregoing, the study therefore examines the effect of relationship marketing as a tool for profitability in banking industry.

\section{Statement of the Problem}

The effect of marketing of bank services in improving banks performance in Nigeria cannot be over emphasized. Nigeria Banks are striving to meet the expectations of their customers in the way and manner they offer financial services to them. The major problem in the Nigerian banking industry is that bank services are still lacking in so many spheres in Nigeria. Yet, the bank's perception of marketing has not shifted from mere advertising until recently as a result of stiff competition among the banks due to recent reforms in the sector. Banks fail to focus on marketing research and new product development that could attract the unbanked thereby leading to inadequate exploitation of its benefits as well as not giving appropriate value to the banking public.

\section{Objectives of the Study}

The specific objective of this study was to determine the impact of relationship marketing as a tool for profitability in Nigeria banking industry.

The objectives of the study are;

1. To ascertain whether relationship marketing of the Nigeria banks improves the bank profitability.

2. To assess whether the presence of valuable and high-quality products \& services enhances the bank profitability.

\section{RESEARCH QUESTIONS}

The following research questions were addressed in this Study;

1. Does relationship marketing in Nigeria banks improve the bank profitability?

2. Does the presence of valuable and high-quality products \& services enhance the bank profitability? 


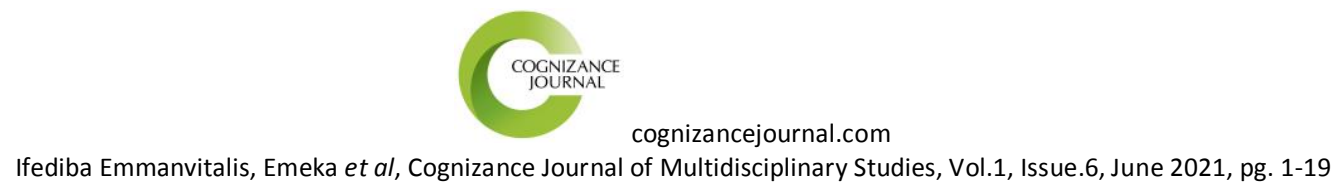

ISSN: 0976-7797

\section{Statement of the Hypothesis}

\section{Hypothesis 1}

$\mathrm{H}_{\mathrm{o}}$; relationship marketing in Nigeria banks does not improve the bank profitability.

$\mathrm{H}_{1}$; relationship marketing of the Nigeria banks improve the bank profitability.

\section{Hypothesis 2}

$\mathrm{H}_{\mathrm{o}}$; the presence of valuable and high-quality products \& services does not enhance the bank profitability.

$\mathrm{H}_{1}$; the presence of valuable and high-quality products \& services enhance the bank profitability.

\section{Literature Review}

Literature review is an important part of a research study as it involves many activities which include identifying, reading, evaluating, describing, summarizing, discussing, citing, and synthesizing various documents with an intention of incorporating them in the study under investigation.

This section deals with Conceptual clarification, Theoretical framework and Literatures on the subject matter. The conceptual framework guides the study and summarizes the dependent and independent variables. The theoretical framework enhances overall framework of the research and deals with the theory that this study anchored on while literature reports on the previous research done by different authors on related topic, how the research was conducted, their observations, findings and their recommendation.

\section{Conceptual Clarification}

\section{Relationship Marketing Concept}

The American Marketing Association's definition of marketing indicates that marketing is an organizational function and a set of processes for creating, communicating, and delivering value to customers and for managing customer relationships in ways that benefit the organization and its stakeholders. Thus, the overall definition of marketing identifies the process of managing 


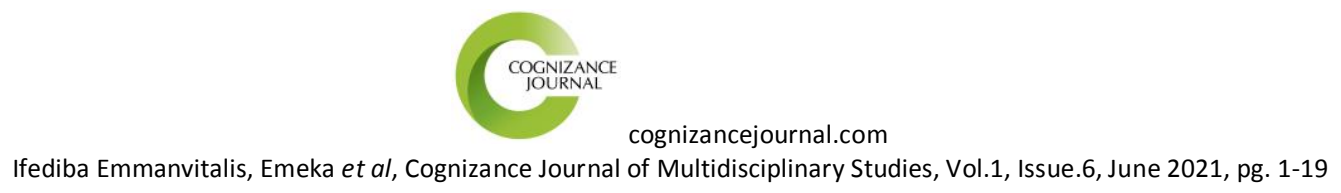

ISSN: 0976-7797

relationships as one of its key charters, parallel to more traditional marketing-mix factors. The domain that deals with "relationships," termed relationship marketing, has been defined in many different ways by scholars from various research perspectives. Relationship marketing is concerned with how a firm relates to its customers and stakeholders and how this, in turn, impacts on business development and the management of customers' needs (Gronroos, 2004). $\mathrm{RM}$ is referred to as a process of attracting, maintaining and enhancing relationships with customers and stakeholders (and, when necessary, terminating them) at a profit, so that the objectives of the parties involved are achieved through mutual exchange and the fulfillment of promises (Zineldin, 2006; Das, 2009; Adamson et al., 2003; Gronroos, 2004 ;)

Relationship marketing involves interactions, relationships and networks as the three central pillars of this marketing perspective (Gummesson, 2003). It also includes the use of databases in which information is compiled, analyzed and reformulated to meet the individual needs of customers. The ongoing, interactive use of customer databases leads to mutually beneficial relationships (Gilbert and Choi, 2003). Adamson et al. (2003) focused on the fulfillment of promises between customers and service providers. RM creates mutual value (Bruhn, 2003) which impacts on how a business develops and how customers' needs are managed (Gronroos, 2004; Bennett and Barkensjo, 2005; Tapp, 2005). Database/interactive marketing's major contribution to RM strategy is to help manage restricted utilitarian exchanges which primarily focus on sales within consumer markets. In addition, database/interactive marketing can be accommodated within the traditional marketing mix paradigm rather forming a new RM paradigm.

\section{Organization Performance}

Measuring and analyzing organizational performance plays an important role in turning organizational goals to reality. The performance is usually evaluated by estimating the values of qualitative and quantitative performance indicators (e.g., profit, number of clients, costs).It is essential for a company to determine the relevant indicators, how they relate to the formulated company goals and how they depend on the performed activities. Nowadays many managers recognize this and put conscious effort in defining company-specific goals, performance indicators and evaluate them. However in practice such analysis is usually done in an informal, 


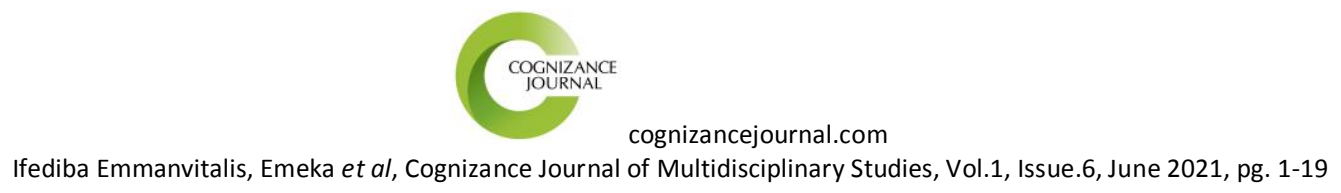

ISSN: 0976-7797

ad-hoc way and will benefit from a more systematic approach (Chan, 2003). The first step towards an improvement in this area is to make explicit the available knowledge on performance indicators and how they are related. In order to use this knowledge in a modern framework for organization modeling it is necessary to formalize the concept of a performance indicator together with its characteristics, relationships to other performance indicators and relations to other formalized concepts such as goals, processes and roles. This will not only contribute to the design and analysis of organizations and the evaluation of their performance but will also enable reuse, exchange and alignment of knowledge and activities between organizations (for example supply chains). Every task in an organization contributes to the satisfaction of one or more organizational goals through performing its process instances. Each goal is formed based on a certain performance indicator(s) which can be measured (directly or indirectly) during or after the process execution depending on the goal evaluation type in the end or during a certain period of time (evaluation period defined as goal horizon)

\section{Effect of relationship marketing on firm performance}

Marketing practitioners and theorists routinely cite the power of the personal referral on customer behaviour which is always achieved through relationship marketing. Rayal \& Payne (2002) developed taxonomy of referral types, broadly split into two groups: customer referrals and non-customer referrals. Customer referrals may be either customer initiated or company initiated. Customer-initiated referrals originate from current or former customers who have been satisfied or delighted with their experiences (Bennett and Barkensjo, 2005). Kotler's (2003) explains that the most effective ways to market your services and brand is through the strong relationships you already have with existing clients. Relationship marketing leads to a greater client experience with your firm. A greater client experience translates into a stellar reputation for your firm, which in turn leads more of the right clients to your door. Creating Stakeholder/shareholders value extends the analysis of the change in the marketing rationale from a crude concern for increased market share to a strategy aimed at creating long-term profitable relationships with targeted customers. For most service organizations, economic success depends on an ability to maintain long-term relationships with customers who purchase their offerings repeatedly (Reinartz, et,al., 2005). Understanding the reasons customers repeatedly purchase from a service firm therefore represents an issue of essential importance, 


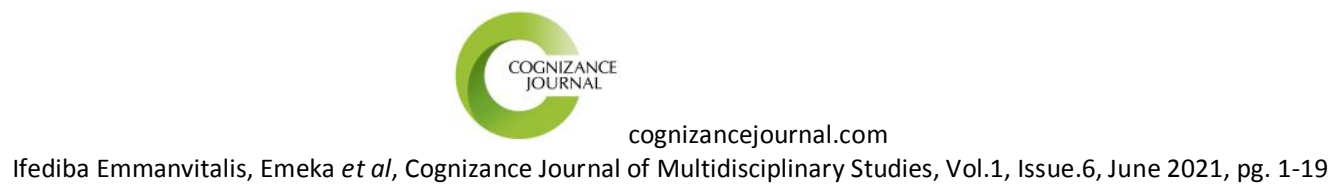

ISSN: 0976-7797

(Ifediba \& Eze 2018). Service research has identified a multitude of potential repeat purchase drivers which among them present relationship marketing initiates put in place by an organization which later creates on loyal consumers. These customers have earned most advantages from the company suggests. Nonetheless, every company should aim goal setting to create loyal customer, but loyalty has never be so strong that customers do not accept those competitor suggestion that have more value (Kotler, 2003). A number of studies have identified that relationship marketing strategies (i.e., financial bonds, social bonds and structural bonds) enhance customer loyalty. Financial bonds enhance customer relationships through special price offers or other financial incentives to loyal customers (Hsieh, Chiu, \& Chiang, 2005).

\section{Components of the Relationship Marketing Orientation (RMO)}

For a business to maximize its long-term performance in such aspects as customer retention, sales growth and profitability, it must build, maintain and enhance long-term and mutually beneficial relationships with its target buyers. Each of the components is described below.

- Trust: Is defined as a willingness to rely on an exchange partner in whom one has confidence. It is essentially the belief that an individual will provide what is promised. The inclusion of trust as a central variable in a relationship exchange has been examined widely in the marketing literature. This study theorizes that the higher the level of trust between buyer and seller, the greater the probability of long-term relationships.

- Bonding: Is defined as the dimension of a business relationship that results in two parties (buyer and seller) acting in a unified manner toward a desired goal. Compared with trust, bonding, as a construct, has received a relatively modest amount of attention from relationship marketing researchers their study theorizes that a long-term buyer-seller relationship requires bonding.

- Communication: Is defined as the formal as well as informal exchanging and sharing of meaningful and timely information between buyers and sellers. Communication, especially timely communication, fosters trust by assisting in solving disputes and aligning perceptions and expectations

- Empathy: Is the dimension of a business relationship that enables the two parties to see the situation from the other person's perspective. Empathy is defined as seeking to understand 


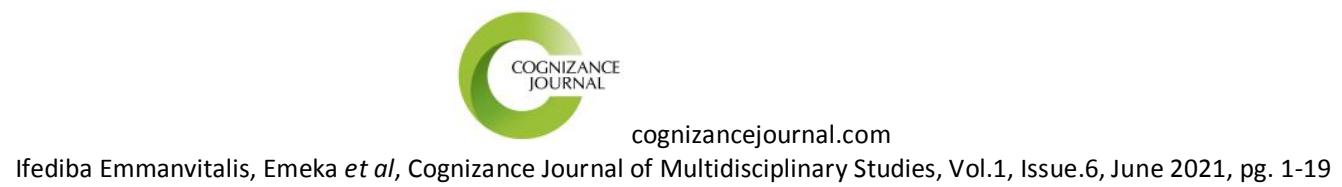

ISSN: 0976-7797

somebody else's desires and goals. In business, this somebody else is often a relative stranger or at best a business connection.

- Reciprocity: Is the dimension of a business relationship that causes either party to provide favors or make allowances for the other in return for similar favors or allowances to be received at a later date.

\section{Theoretical framework}

Every substantial phenomena, is bound to have logical and empirical explanations. It is in such situations that theories prove their utmost value, especially in scholarly endeavors.

\section{Commitment-Trust theory of Relationship Marketing}

This theory of relationship marketing was posited by Morgan \& Hunt in (1994), they noted that commitment and trust are vital for any successful relationship. They further posited that relationship marketing involves creating a unique tie with your customers by ensuring their needs are met, honoring commitments other than focusing on short term profits. Thus, in ensuring customers' loyalty is achieved, there would be repeated patronage and referrals which would beef-up the profits of the company. Product innovation has the potential of opening new markets if a particular brand has proven to be of high quality. When customers retain the new innovated products, it has the potential to protect the firm from market threats and competitors. (Hult et al., 2004) as cited in (Centobelli et al., 2019).

\section{Empirical Review}

Toequipmentny, \& Tracey, (2007) study aimed at examining whether or not the relationship characteristics of length and duration, the customer demographic characteristics of age and gender and relationship attribute importance, as perceived by the customer, have an impact on the strength of the relationship between the customer and service provider. The study used a field survey where 287 questionnaires were distributed over the customers of five service products of which, the sample was asked to assess the strength of the relationship between themselves and their supplier. The study found that the relationship strength was found to vary significantly between service products and individual customers, and the impact of duration of the relationship and the frequency of purchase on relationship strength depends greatly on the nature of the 


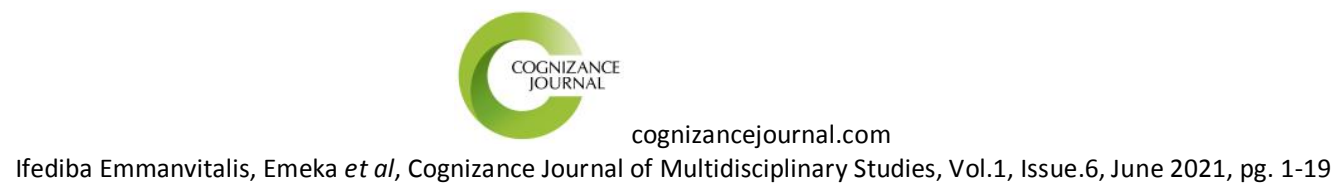

ISSN: 0976-7797

service product. It was also demonstrated that some customers want a closer relationship with service providers than other customers, and this aspect significantly affects the strength of relationship perceived by the customer

Rasheed Saeed et al, (2013) conducted a study fitted impact of Customer Relationship management on customer satisfaction revealed that stronger relationship with customers have a great impact in order to satisfy their customers. The study adopted survey research design with a population of 10 deposit money banks. The study shows a positive and significant relationship between Customer Relationship Management and customer satisfaction.

Using simple percentage and chi-square methods in testing the hypotheses of the effect of marketing on bank performance in Nigeria, Yakubu. (2012) found that marketing has positive impact on the performance of the banking industry in Nigeria.

Using descriptive survey and regression analysis statistics in investigating the relationship between marketing and bank performance in Nigeria, Kosile and Ajala (2012) observed that there is positive and significant relationship between relationship marketing and bank performance indicators in Nigeria. It was also found that direct and internal marketing are insignificant predictors of bank performance in Nigeria

Bolanle and Emmanuel (2016) study examined the impact of relationship marketing on customer satisfaction. The undergraduate students in a private university in Oyo State Nigeria were their case study. Questionnaire was employed in gathering related data from the respondents. Pearson correlation and multiple regression analysis were used in testing the hypothesis. The result of the study reveals that relationship marketing has a significant effect on customer satisfaction.

\section{Research Methodology}

Research methodology is defined as the systematic process or procedure designed for generating, collecting, and analyzing the data required for solving a specified problem. This chapter discusses the ways and means through which the study was carried out. It also presents the research Area of Study, Source of Data, Sampling Technique. Method of Data Collection, Method of Data Analysis, Reliability of Instruments and Validity of Instrument. 


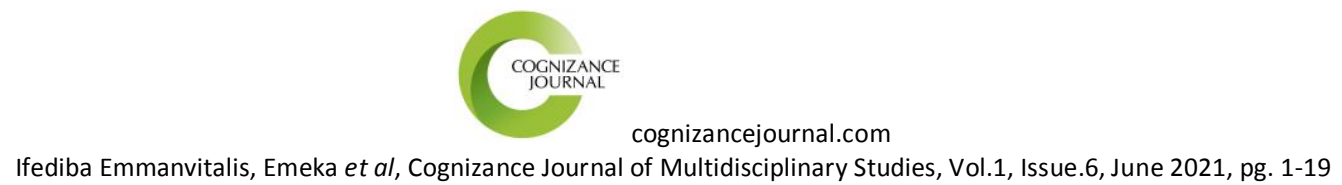

ISSN: 0976-7797

\section{Area of Study}

The area of the study covers 10 commercial licensed banks operating in island and mainland in Lagos Metropolis, Lagos state. These formed the population for the study. This being a survey all the 10 banks were incorporated in the study.

\section{Sources of Data}

The researcher employed the use of both the primary and secondary sources of data. Primary sources of data are firsthand information. The data is generated by the researcher for the purpose of the study, primary data collected for this study are questionnaires given to the enterprises under study to elicit responses. While that of the secondary data are facts that the researcher collected from already existing sources. The secondary sources from which data were generated are newspapers, textbooks, magazines, journals, published research work, memo-graphs.

\section{Sampling Techniques}

The simple random sampling technique is employed, giving each member of the population an equal chance. A sample size of 120 persons was selected at random, using Bourley (1998) proportional allocation formula, it was distributed as follows: bank managers (18), heads of customer relationship management (55) and staff in the private sectors (47). One hundred (110) were used for data analysis

A pre-test was conducted and outcome yield " $\mathrm{r} "=0.92$ indicating a high degree of consistency and reliability. The instrument was 8- term survey questionnaire with a - 5 Likert scale response options of Very Relevant (VR), Relevant(R), No Effect (NE) Irrelevant (I), and Very Irrelevant (VI). The questionnaire was structured in line with their search objectives, questions and hypothesis of the study. The Pearson product moment correlation coefficient was used to confirm formulated hypotheses.

\section{Method of Data Collection}




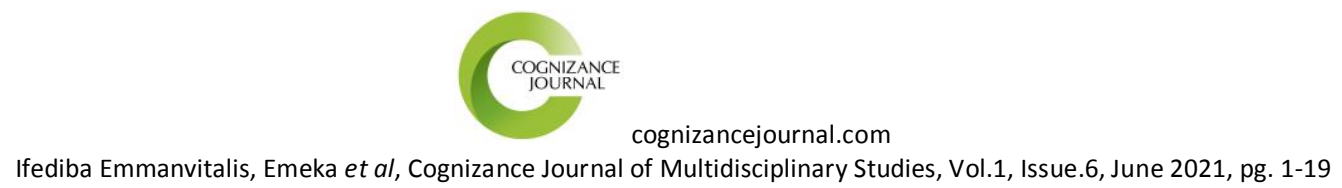

ISSN: 0976-7797

The data for the main study was collected from banks located in island \& mainland. The questionnaire titled "Relationship Marketing Practices as a tool for profitability in Banking industry" and a cover letter explaining the purpose of the survey were personally administered to the ten corporate banking relationship marketing managers of each bank. The respondents were allowed a two weeks period to fill out the questionnaires. After one week the researcher sent a reminder to all the respondents. The questionnaires were collected after the second week.

\section{Method of Data Analysis}

The questionnaire was structured in line with the research objectives, questions and hypothesis of the study. The response gotten from the questionnaires were presented in tabular forms. The Pearson product moment correlation coefficient was used to confirm formulated hypotheses which show the magnitude of the discrepancy between the variables, expectation and observation. The test was carried out at $0.5 \%$ level of significance using SPSS statistical tool.

Pearson correlation is represented as follows:

$\mathbf{R}=\mathbf{N} \Sigma \mathbf{X Y}-(\mathrm{XY})(\Sigma \mathrm{Y})$

$\left.\left.\sqrt{[N} \mathbf{X} Y^{2}-(\mathrm{X})^{2}\right] \sqrt{[N} \Sigma \mathbf{Y}^{2}-(\mathrm{Y})^{2}\right]$

\section{Reliability of the Instrument}

A pre-test was conducted and outcome yield " $r$ " $=0.99$ indicating a high degree of consistency and reliability. The internal consistency for this instrument is considered high and acceptable given a result of 0.99 .

\section{Validity of Instrument}

The research instrument was presented to experts in the department of marketing in National Open University Lagos Nigeria; who validated it. Suggestions and corrections were taken cognizance of and effected before the administration of the instrument to respondents. 


\section{Data Analysis}

The results of the analysis based on the hypotheses tested are as shown below:

Table 1: Distribution and return of questionnaires

\begin{tabular}{ccc}
\hline S/N & Option & Frequency \\
\hline 1. & Total Distributed & 120 \\
2. & Total not Returned & 10 \\
\hline & Total Analyzed & $\mathbf{1 1 0}$ \\
\hline
\end{tabular}

Source: Field survey, (2020)

Table 2: Distribution of questionnaires to banks and locations

\begin{tabular}{llll}
\hline S/N & Banks & Locations & Frequency \\
\hline 1. & First & island & 1 \\
2. & Zenith & island & 2 \\
3. & GT & island & 2 \\
4. & UBA & island & 1 \\
5. & Access Diamond & island & 1 \\
6. & Polaris & mainland & 1 \\
7. & Heritage & mainland & 1 \\
8. & Sterlingmainland1 & & 1 \\
9. & Wemamainland & & 1 \\
10. FCMB & mainland & $\mathbf{1 0}$ \\
\hline
\end{tabular}

Source: Field survey, (2020) 
Table 3: Summary of Hypotheses Test Results

\begin{tabular}{ccccccc}
\hline $\mathrm{H} / \mathrm{N}$ & QS & Cal."”r" & LS (x) & Inference & Correlation & Decision \\
\hline & & & & & \\
1. & A & 0.99 & 0.5 & $\mathrm{r}>\mathrm{x}$ & Highly positive Accept Alternate \\
2. & B & 0.87 & 0.5 & $\mathrm{r}>\mathrm{x}$ & Highly positive Accept Alternate
\end{tabular}

Source: Research computation, (2020). Keys: HN=Hypotheses Number; QS=Questionnaire section; LS= Level of significance.

Table 4: Response on whether relationship marketing in Nigeria banks improves the bank profitability?

\begin{tabular}{clcccc}
\hline Option & Points & Response (y) & $\mathrm{xy}$ & $\mathrm{x}^{2}$ & $\mathrm{y}^{2}$ \\
\hline VR & 5 & 60 & 300 & 25 & 3600 \\
V & 4 & 22 & 88 & 16 & 484 \\
NE & 3 & 10 & 30 & 9 & 100 \\
I & 2 & 1 & 38 & 4 & 1 \\
VI & 1 & 17 & 17 & 1 & 289 \\
& & & & & \\
\hline Total & $\mathbf{1 5}$ & $\mathbf{1 1 0}$ & $\mathbf{4 7 3}$ & $\mathbf{5 5}$ & $\mathbf{4 4 7 4}$
\end{tabular}

Source: Researcher's computation (2020). Key: Very Relevant (VR), Relevant(R), No Effect (NE) Irrelevant (I), and Very Irrelevant (VI). 
cognizancejournal.com

Ifediba Emmanvitalis, Emeka et al, Cognizance Journal of Multidisciplinary Studies, Vol.1, Issue.6, June 2021, pg. 1-19

ISSN: 0976-7797

Table 5: Response on whether presence of valuable and high-quality products \& services enhances the bank profitability?

\begin{tabular}{cllccc}
\hline Option & Points & Response (y) & $\mathrm{xy}$ & $\mathrm{x}^{2}$ & $\mathrm{y}^{2}$ \\
\hline VR & 5 & 50 & 250 & 25 & 2,500 \\
V & 4 & 19 & 76 & 16 & 361 \\
NE & 3 & 1 & 3 & 9 & 1 \\
I & 2 & 20 & 40 & 4 & 400 \\
VI & 1 & 13 & 13 & 1 & 169
\end{tabular}

$\begin{array}{llllll}\text { Total } & 15 & 110 & 382 & 55 & 3,431\end{array}$

Source: Research computation, (2020). Key: Very Relevant (VR), Relevant(R), No Effect (NE)

Irrelevant (I), and Very Irrelevant (VI).

\section{Hypothesis 1}

$\mathrm{H}_{\mathrm{o}}$; relationship marketing in Nigeria banks does not improve the bank's profitability.

$\mathrm{H}_{1}$; relationship marketing in Nigeria banks improve the bank's profitability.

Here, using table 4 to answer to test hypothesis 1 . We apply the formula stated above;

$$
\begin{aligned}
& \mathbf{R}=\mathbf{N} \Sigma \mathbf{X Y}-(\mathrm{XY})(\boldsymbol{\Sigma Y}) \\
& \sqrt{\left.\left[\boldsymbol{N} \mathbf{X Y} \mathbf{Y}^{2}-(\mathrm{X}){ }^{2}\right] \sqrt{[N} \Sigma \mathbf{Y}^{2}-(\mathbf{Y})^{2}\right]} \\
& =\frac{5(473)-(15 \times 110)}{\left[(5 \times 55)-(15)^{2}\right]\left[(5 \times 4474)-(110)^{2}\right.} \\
& =\frac{2,365-1650}{\sqrt{(275-225)(22,370-12100)}}
\end{aligned}
$$


cognizancejournal.com

Ifediba Emmanvitalis, Emeka et al, Cognizance Journal of Multidisciplinary Studies, Vol.1, Issue.6, June 2021, pg. 1-19

ISSN: 0976-7797

$=715$

717

$=0.99(99 \%)$

In hypothesis1, the $\mathrm{r}$ calculated of $0.99>0.5$ level of significance. The alternate hypothesis is accepted. This shows that relationship marketing in Nigeria banks improve the bank's profitability. Though the variables have high positive correlation, this implies that the commercial bank's is waxing strong to ensure that their bank staff is regularly trained in customer relationship issues.

\section{Hypothesis 2}

$\mathrm{H}_{\mathrm{o}}$; the presence of valuable and high-quality products \& services does not enhance the bank profitability.

$\mathrm{H}_{1}$; the presence of valuable and high-quality products \& services enhance the bank profitability.

Here, using table 5 to answer to test hypothesis 2 . We apply the formula stated above;

$$
\begin{aligned}
& \mathbf{R}=\mathbf{N} \boldsymbol{\Sigma} \mathbf{X Y}-(\mathbf{X Y})(\boldsymbol{\Sigma Y}) \\
& \left.\sqrt{[\mathbf{N} \mathbf{X Y}} \mathbf{Y}^{2}-(\mathbf{X})^{2}\right] \sqrt{\left[\boldsymbol{N} \Sigma \mathbf{Y}^{2}-(\mathbf{Y})^{2}\right]} \\
& =\frac{5(382)-(15 \times 110)}{\left[(5 \times 55)-(15)^{2}\right]\left[(5 \times 3431)-(110)^{2}\right.} \\
& =\frac{1,910-1650}{\sqrt{(275-225)(17155-12100)}} \\
& =\frac{260}{503} \\
& =0.52(52 \%)
\end{aligned}
$$

In hypothesis 2 , the $\mathrm{r}$ calculated of $0.52>0.5$ level of significance. The alternate hypothesis is accepted. This shows that the presence of valuable and high-quality products \& services (C2021, Cognizance Journal, cognizancejournal.com, All Rights Reserved 


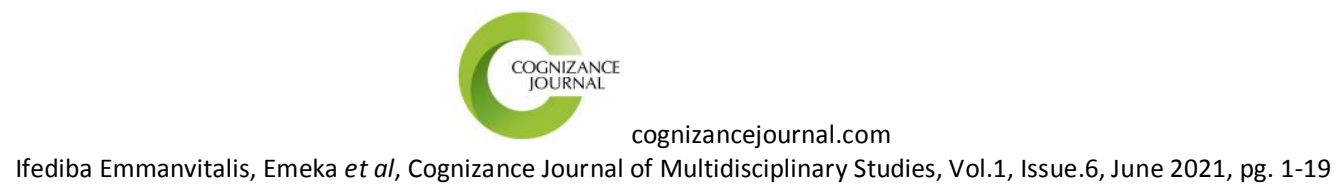

ISSN: 0976-7797

enhances the bank profitability. This implies that the commercial banksare coming up with customized products and services as well as conducting financial services seminars. The banks were also communicating with customers regularly to inform them of new products and services as part of their relationship marketing initiatives through their comprehensive data collection system which enables collection of customer's views.

\section{Findings}

At the end of this study, the following findings are made;

1. The alternate hypothesis is accepted showing that relationship marketing in Nigeria banks improve the bank's profitability. Though the variables have high positive correlation, this implies that the commercial bank's is waxing strong to ensure that their bank staff is regularly trained in customer relationship issues.

2. The alternate hypothesis is accepted. This shows that the presence of valuable and highquality products \& services enhances the bank profitability. This implies that the commercial banks are coming up with customized products and services as well as conducting financial services seminars. The banks were also communicating with customers regularly to inform them of new products and services as part of their relationship marketing initiatives through their comprehensive data collection system which enables collection of customer's views.

\section{Conclusion}

On the effect of relationship marketing, this study summarizes that commercial banks had managed to increase their products in the recent years hence making it grow, customers tend to stay with this service provider for a long period of time, the market share of the company have been increasing tremendously recently, there are enough staff who ensure customer satisfaction is achieved and ultimately improving the most of the banks reputation.

Customer satisfaction and loyalty is said to be the most essential elements for success and profitability of organization in every sector of business enterprise, hence, the more a firm satisfies its clients, the likelihood of them developing increased loyalty and the tendency of 


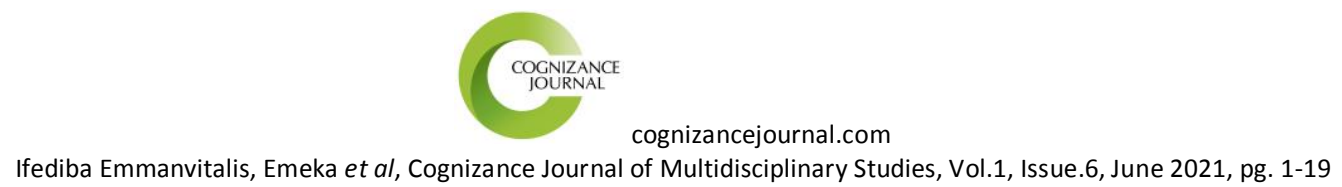

ISSN: 0976-7797

evolving durable relationships. However, it is important to note that with the swelling growth in the number of banks and its resultant hypercompetitive outlook, managers of most banks will have to persistently struggle in search of alternative action plans that will not only enhance the drive to attract new customers but also build a long-term friendly business relationship in order to grow shareholder fund and become profitable.

\section{Recommendations}

The following recommendations are made;

1. This study recommends that since there is a positive influence on the use of RM practices, evaluation and monitoring of the said activities need to be optimized so as to avoid unnecessary costs or losses trying to fit them in retaining or satisfying customers. The right RM practices should be adopted, in the right manner, at the right time and with the application of the right approaches. This will enhance banks in improving their approaches to customer management, profitability increase and customer trust and loyalty creation.

2. This study recommends the relation managers and other managers, the staffs in the related departments and other stakeholder involved in matters of the bank's operations continue with the spirit of understanding the requirements of RM, as well as other issues that govern it. The management should come up with RM programs to ensure that employees are well trained on the extent of importance of RM practices adoption towards the performance of a commercial bank. This will mean that every other staff in the bank organization understands well on RM best practices that can be used to enhance the performance both in terms of financial and non-financial measures.

\section{Implications of the Study}

- The findings of the research are expected to help the academicians, marketing practitioners to view relationship marketing as a holistic approach to the business for future sustainability.

- Besides, the future research can also focus on a longitudinal study where the progress of the banks ${ }^{\text {ee }}$ performance can be closely monitored throughout the time and necessary measures can be implemented to fruitfully retain customers in the future. 


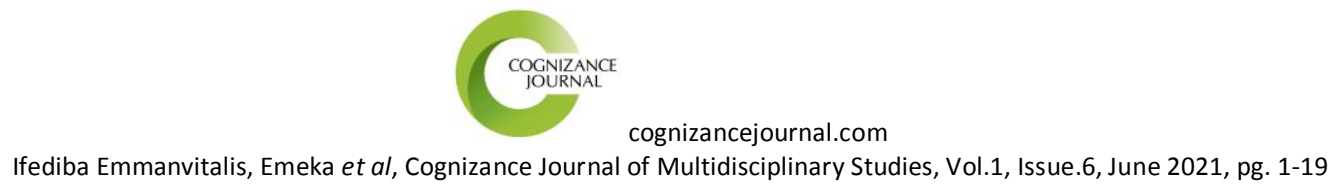

ISSN: 0976-7797

- It is suggested that further research should be carried out on relationship marketing in microfinance institutions and rural banks in Nigeria.

\section{References}

[1]. Adamson, I., Chan, K. M. and Handford, D. (2003). Relationship marketing: customer commitment and trust as a strategy for the smaller Hong Kong corporate banking sector. International journal of bank marketing. 21(6/7), pp. $347-358$.

[2]. Bennett, R. and Barkensjo, A. (2005). Relationship quality, relationship marketing, and client perceptions of the levels of service quality of charitable organizations. International journal of service industrial management. 16(1), pp. 81-106.

[3]. Bolanle, O and Dunmade, E ( 2016) impact of relationship marketing on customer Satisfaction: a case study of the undergraduate Students in a private university, oyo state, Nigeria. International Journal of Economics, Commerce and Management United Kingdom 4;2 http://ijecm.co.uk/

[4]. Brige, A. (2006). Building relationship with customers by using technological solutions in commercial banks of Latvia. Baltic Journal of Management, 1(1), 24-33.

[5]. Bruhn, M. (2003). Relationship marketing: management of customer relationships. London: Prentice Hall.

[6]. Centobelli, P. Cerchione, R., \& Singh, R. (2019). The impact of leanness and innovativeness on environmental and financial performance: Insights from Indian SMEs. International Journal of Production Economics, 212, 111-124.

[7]. Chan. F (2003). Performance measurement in a supply chain. International Journal of Advanced Manufacturing Technology. 21(7), 2003, 534-548.

[8]. Chiang, M, Chiu, H. and Hsieh, (2005). Relationship marketing and consumer switching behavior. Journal of Business Research. 58(12): 1681- 1689.

[9]. Das, K. (2009). Relationship marketing research (1994-2006): An academic literature review and classification. Marketing intelligence \& planning, 27(3), pp. 326- 363.

[10].Dimitriadis, S. (2011). Customers' relationship expectations and costs as segmentation variables: Preliminary evidence from banking. Journal of Services Marketing, 25(4): 294-308.

[11].Estrella-Ramón, A. (2017). Explaining customers' financial service choice with loyalty and crossbuying behaviour. Journal of Services Marketing, 31(6): 539-555.

[12].Gilbert, D. C. and Choi, K. C. (2003). Relationship marketing practice in relation to different bank ownerships: a study of banks in Hong Kong. International journal of bank marketing, 21(3), pp. $137-146$.

[13].Gronroos, C (2004). The relationship marketing process: communication, interaction, dialogue value, Journal of business and industrial marketing, 19(2), pp. 99-113.

[14].Gummesson, E. (2003). Total relationship marketing', Business seminar ICRM 2003. University of Gloustershire, Cheltenham, UK. August 2013. Available at: www.fek.su.se/home/eg/ (Accessed: date 1st August 2013).

[15].Hult, G, Hurley, R, \& Knight, G. (2004). Innovativeness: Its antecedents and impact on business performance. Industrial marketing management, 33(5), 429-438.

[16].Ifediba, E and Eze, F. (2018). Using the servoual model to evaluate the service delivery of the consumer protection council in Nigeria, European journal of business and management at ISSN 2222-1905 (paper) ISSN 2222-2839 (Online).

[17].Kosile, B. and Ajala, A. (2012). Relationship Between and Bank Performance: An Applied Study on Commercial Bank in South Western Nigeria. Europeum Journal Business and Management. 4(10); 102-111.

[18].Kotler, P. (2003). Marketing Management. (11th Ed.). New Delhi: Pearson education. 
cognizancejournal.com

Ifediba Emmanvitalis, Emeka et al, Cognizance Journal of Multidisciplinary Studies, Vol.1, Issue.6, June 2021, pg. 1-19

ISSN: 0976-7797

[19].Morgan, R.M., \& Hunt, S.D. (1994). The commitment-trust theory of relationship marketing. Journal of Marketing, 58(3), 20-38.

[20].Rasheed, S., Rab N, Sarwat N. and Uzammit, M. (2013) impact of customer relationship management on customer satisfaction. Balina University Islamabad Pakistan.

[21].Reinartz, W, Thomas J \& Kumar V. (2005). Balancing acquisition and retention resources to maximize customer profitability. 69(1):63-79.

[22].Rezghi, A. R., Valmohammadi, C., \& Yousefpoor, J. (2014). The relationship between customer satisfaction and customer relationship management system: A case study of Ghavamin Bank. Industrial and Commercial Training, 46(4): 220-227.

[23].Ryals, L. and Payne, A. (2001). CRM in financial services: towards information enabled relationship marketing. Journal of strategic marketing. 9, pp. 3-27.

[24].Selvan, P. (2000). Relationship between Marketing of Financial Services and Bank Performance in Malaysia: An Empirical Study. Being a Master's Degree Project submitted to the Postgraduate School for a Master of Business Administration (MBA) Degree, University of Malaysia.

[25].Tapp, A. (2005). Principles of direct and database marketing. 3rd ed., Pearson Education, Harlow.

[26]. Toequipmentny, W. and Tracey, S. (2007), The complexity of relationship marketing for service customers, Tony Ward and Tracey S. Dagger (2007), The complexity of relationship marketing for service customers, Journal of service Marketing, 21(4); 281-290.

[27]. Yakubu. A. (2012). Impact of Relationship Marketing on the performance of Banking industry in Nigeria. Being a Masters Project submitted to the Post Graduate school of Ahmadu Bello University, Zaria for the award of Master of Business Administration (MBA) Degree, 1-76.

[28].Zineldin, M. (2006). The royalty of loyalty: CRM, quality and retention. Journal of consumer marketing. 23(7), pp. 430-437. 